\title{
Synthetic Formaldehyde.
}

$\mathrm{F}^{0}$

ORMALDEHYDE, which is great by in demand for disinfection and for the manufad the of artificial resins and synthetic dyes agedfors, was at one time chiefly imported into gregl Britain as a 40 per cent. aqueous solution (formb(r) at a price which stimulatod investigations ift the possibility of its synthetie production. Since it is made by the cataly tic dehydrogenation of methyl alcohol, usually over a copper contact mass, its price will naturally be dependent on that of wood spirit, and hence on the demand for wood ehar coal, unless alternative supplies of the alcohol become available, as is now in fact the case. The falling exports of wood distillation products from the United States of America, and the large natural sources of gaseous hydrocarbons within the Fmpirc, are facts which indicated clearly enough the direction in which rescarch should be undertaken. The Chemistry Research Board of the Department of Scientific and Industrial Research consequently decided to explore the possibility of the economical production of formaldehyde by the oxidation of hydrocarbons.

The work was carried out at the Royal Naval Cordite Factory, Holton Heath, Dorset, and is the subject of a report entitled "The Production of Formaldehyde by Oxidation of Hydrocarbons" (Chemistry Research, Special Report No. 1) by Messr's. W. Ledbury and E. W. Blair, which hus just been published by H.M. Stationery Office (2s. net). This report deals both with the production of the formaldehyde and with its recovery from aqueous solutions. Although the account of the investigations shows that the formalde hyde can be manufactured according to the proposed process in the form of a dilute solution, it is pointed out that the commercial success of the method has been forestalled by a greater success : that of the manufacture of methyl alcohol ('methanol') from mixtures of carbon monoxide and hydrogen. By this means the price of formaldehyde has been reduced from $£ 130$ to $£ 40$ por ton, and even the United States of America is importing from Germany supplies of this commodity.

Valuable information, however, has been gained in connexion with the concentration of dilute formaldehyde solutions, and the Board has wisely decided to place on record the whole of the data. The Report first describes the production of formaldehyde by the controlled oxidation of ethylene, methane, etc.; much of the work has already been published in detail, and is therefore familiar to those interested in the subject. The Report covers the transition of the laboratory experiments to semi-technical processes; the use of coal gas has also been examined, but the cost was found to be prohibitive except during errergency periods. A serri-technical investigation of the absorption by water of dilute formaldehyde vapours is next described, and reference is made to tho bisulphite and ammonia compounds of formaldehyde.

The section on the recovery of formaldehyde from aqueous solutions commences with a description of a laboratory investigation of the distillation of formaldehyde solutions at atmospheric pressure, followed by the results of large-scale tests, and exporiments on distillation under pressure and contirnuous distillation. Incidentally, it was found that iron, even in the form of an alloy containing only 9 per cent. of that metal, is unsuitable for use in the construction of stills for formaldehyde solutions on account of its activity in causing decomposition of that compound, whilst nickel, aluminium, and copper are non-reactive. The cost of concentration appears to be such that it is uneconomical to concentrate by distilla. tion a solution appreciably weaker than $1 \cdot 5$ per cent.

\section{History 5 of the Desert Flora of the Old World.}

$\mathrm{D}$ ETAILED analysis of No systematics and distri bution of var 3 ppyical desert plants of central Asia has led the ユ्Ass un botanist, M, G. Popov, to some very interesting general considerations on the origin and history of the desert flora of the Old World (Bull. Univ. Asie Centrale, Tashkent, livr. 15, 1927, pp. 239-292).

According to Popov's views, the primitive desert flora developed so early as in the Cretaceous, or even the Jurassic period. To this time must belong such forms as Welwitchia, Ephedra, ete., and the centre of origin must have been in the central parts of the Gondwana continent. Destruction of the latter resulted in the shifting of the main desert area into the southern hernisphere, where a continuous landmass existed during the Cretaceous period and a free exchange of desert forms betwcen South Africa, South America, and Australia could take place. During this period such great groups of desort plants were devcloped as Zygophyllaceæ, Geraniaceæ, Rutaceæ, Capparidacea, otc., and for this complex of forms the author proposes the name of the Welwitchia flora.

At the same period the African continent was connected by the Lemurian with India, and over this bridge desert forms from South Africa migratod through the Deccan into central Asia, while northward migration of the desert flora on the African continent itself went so far north as the southern shores of the sea of Thetis, which occupied the place of the Sahara. Thetis separated the region of the Welwitchia flora from more northern parts of the Arctogea, where a very different mesophilous flora, which originated on the Angara continent, developed.

Parallel with the migration of purely desert elements from South Africa northwards, there was an interchange of less xcrophilous plants between westorn $\Lambda$ sia and South Africa, by way of East African table-lands; in this way Erica, for examplo, migrated from south to the north, and Dianthus in the opposite direction. The disappcarance of the Lemurian bridge separated the South African desert region from Asia, while the lowering of the East African mountains resulted in its separation from the Mediterranean deserts.

A further stage of the development was due to the disappcarance of the 'Thetis sea, in place of which the vast desert belt stretching from Sahara to Mongolia developed. These deserts were invaded by the Welwitchia flora which already flourished on the southern shores of the Thetis. In this way the very uniform ancient Mediterranean flora was formed, and its further evolution consisted in extensive interchange of forms with America, by way of the Northern Atlantic. This, together with the dying-out of many ancient elements of the Welwitchia flora in the Palæarctic deserts, owing to changes of edaphic conditions, led to further changes in the flora of the latter now entirely separated from the South African desert region. As a result, a special desert flora was evolved, which may be called ancient Mediterranean, or Iranian, but its history is to be discussed in a later paper by the same author.

No. 3031, Vox. 120] 